\title{
Peatland vegetation change and establishment of re-introduced Sphagnum moss after prescribed burning
}

\author{
Alice Noble ${ }^{1}$ (D) Sheila M. Palmer ${ }^{1} \cdot$ David J. Glaves $^{2} \cdot$ Alistair Crowle $^{2}$. \\ Joseph Holden ${ }^{1}$
}

Received: 6 July 2018 / Revised: 5 January 2019 / Accepted: 12 January 2019 / Published online: 8 February 2019 (C) The Author(s) 2019

\begin{abstract}
Fire, including prescribed burning, is common on peatlands globally and can affect vegetation, including peat-forming Sphagnum mosses, and affect ecosystem services. We monitored vegetation in different burn-age categories at three UK peatland sites over a 19-month period. Half of the plots had Sphagnum fragments added and their survival was assessed. Changes in vegetation composition over time, and associations between vegetation composition, site and burn-age category were investigated. Plots in the most recently burned category were likely to have more bare peat, a thinner moss layer and lower vascular plant strata. Graminoid cover initially increased after burning but was low after $10+$ years. Dwarf shrub cover increased after burning and remained high after $10+$ years. At the most Sphagnum-rich site, a high proportion of existing Sphagnum cover was bleached one year after burning, but recovery occurred during the study period. Sphagnum re-introduction success decreased over the study period in the most recent and intermediate burn-age categories at the most Sphagnum-poor site. These results show that burning rotation length is an important factor in determining site-level vegetation composition on burned sites. More frequent burning will result in a greater proportion of land in the early post-burning stages, potentially resulting in a thinner moss layer, more bare peat and less healthy Sphagnum, with potential consequences for carbon balance. No evidence was found to support the use of burning as a tool to increase existing Sphagnum or promote Sphagnum re-establishment success.
\end{abstract}

Keywords Blanket bog $\cdot$ Fire $\cdot$ Heather $\cdot$ Land management $\cdot$ Moss $\cdot$ Succession

Communicated by Frank Chambers.

Electronic supplementary material The online version of this article (https://doi.org/10.1007/s1053 1-019-01703-0) contains supplementary material, which is available to authorized users.

Alice Noble

gyakn@leeds.ac.uk

water@leeds, School of Geography, University of Leeds, Leeds, UK

2 Natural England, Foss House, Kings Pool, Peasholme Green, York, UK 


\section{Introduction}

Peatlands are important carbon stores (Yu et al. 2010), covering around 423 million ha globally (Xu et al. 2018). In a healthy state, peatland ecosystems have the potential to accumulate carbon (Clymo et al. 1998), support biodiversity (Littlewood et al. 2010) and regulate hydrological processes (Labadz et al. 2010). However, degradation due to anthropogenic influences can threaten peatland function (Evans et al. 2014). In particular, vegetation change has the potential to harm the provision of ecosystem services (Grayson et al. 2010; Holden et al. 2008; Nichols et al. 2014; Ritson et al. 2016).

On northern hemisphere blanket peatlands, vegetation often largely consists of mosses, graminoids and dwarf shrubs. Vegetation composition plays a central role in ecosystem function, and although a range of species occur naturally on blanket peatlands, some may have a detrimental impact when dominant. Mosses can make up a significant component of the vegetation and include Sphagnum mosses which are of central importance for peat formation (van Breemen 1995) and water quality (Armstrong et al. 2012; Ritson et al. 2016), but require relatively wet conditions (Price and Whitehead 2001) and can be pollutionsensitive (Ferguson et al. 1978; Gunnarsson and Rydin 2000). A variety of pleurocarpous and acrocarpous moss species are also found on peatlands. However, differences in water storage capacity (Elumeeva et al. 2011) as well as net ecosystem exchange and decomposition rates (Orwin and Ostle 2012) mean that these groups do not support peat accumulation to the same extent as Sphagnum. Vascular plants including graminoids and dwarf shrubs contribute to the structural diversity of peatland habitats (Malmer et al. 1994) and can provide food and shelter for livestock and wildlife (Garnett et al. 2000; Robertson et al. 2017; Thompson et al. 1995). Some graminoid species, such as the sedge Eriophorum vaginatum, can also contribute to peat formation (Kalnina et al. 2015; McClymont et al. 2011). However, dominance of some vascular plants, such as Calluna vulgaris, may increase the amount of carbon lost as dissolved organic carbon (DOC) and $\mathrm{CO}_{2}$, potentially owing to their impact on water table and soil temperature (Armstrong et al. 2012; Dixon et al. 2015).

Prescribed vegetation burning occurs on many peatlands worldwide for purposes including agricultural production and wildfire risk management. In the UK, it is often used as a vegetation management tool on blanket peatlands, particularly to improve habitat for the game bird red grouse (Lagopus lagopus scotica) on sport shooting estates (Douglas et al. 2015). Patches of up to around $4000 \mathrm{~m}^{2}$ are burned on a rotation of c.7-25 years to produce a mosaic of vegetation ages suitable for foraging and nesting (Thacker et al. 2015). Burn severity varies, but good practice guidelines recommend 'cool' burns which remove the canopy layer of vegetation without consuming the moss or litter layer or igniting underlying peat (Defra 2007; Scottish Government 2011). The area of UK peatlands managed by burning has increased in recent decades (Douglas et al. 2015; Thacker et al. 2015; Yallop et al. 2006), causing concern about potential impacts on peatland function and debate about the sustainability of current practice (Allen et al. 2016; Brown et al. 2016; Harper et al. 2018).

Past research has shown that burning is associated with altered vegetation communities and that the abundance of key species can fluctuate in the years following burning (Noble et al. 2018). However, timescales of change after burning, and variation in the process between sites, remain poorly understood. For Sphagnum, understanding post-burning change is complicated by the fact that water deficiency or temperature damage can cause visible bleaching and reduced photosynthetic efficiency (Harris 2008; Taylor et al. 2017), but recovery of affected tissue or regeneration via new growth from this state may be 
possible (Taylor et al. 2017). Knowledge of when important vegetation changes occur in the post-burning trajectory will aid our ability to place past research into context and help to inform monitoring and land management decisions.

Sphagnum re-introduction via deliberate human intervention can be used as a tool to reinstate peat-forming vegetation as part of peatland restoration projects (Chirino et al. 2006; Ferland and Rochefort 1997; Gunnarsson and Söderström 2007; Robroek et al. 2009). Sphagnum re-introductions have taken place on some degraded UK peatlands, where historically abundant Sphagnum has been reduced by drivers including pollution and drainage (Carroll et al. 2009). Sphagnum can be added in the form of vegetative diaspores (Campeau and Rochefort 1996), plugs, or contained within manufactured products including beads and gel (Hinde et al. 2010). Past work has investigated influences on Sphagnum establishment success, including water availability (Noble et al. 2017; Robroek et al. 2009), nutrient status (Noble et al. 2017), propagule size (Gunnarsson and Söderström 2007) and climatic conditions (Chirino et al. 2006). However, it is not known how time since burning impacts establishment success of added Sphagnum. Increased knowledge in this area would be helpful when planning re-introductions on previously burned sites. Additionally, it has been suggested that burning may be useful as a restoration tool to remove dominant dwarf shrub canopies and facilitate Sphagnum establishment (Uplands Management Group 2017), but more evidence is needed to determine the effectiveness of such an approach (Lunt et al. 2011; IUCN 2017).

In this study, we aim to understand timescales of vegetation change and the potential for establishment of re-introduced Sphagnum after burning, and consider variation in these processes between sites. Specifically, we hypothesise that burning affects key plant groups with the capacity to influence ecosystem services. We also hypothesise that impact timescales differ between plant groups because of differences in their environmental tolerances and growth forms. By monitoring existing vegetation over 2 years at three blanket peatland sites, using plots which had different durations since they were last burned, we were able to construct a timeline of post-burning change in key plant groups and infer potential impacts on peatland ecosystem services. Measuring survival and growth of Sphagnum added to duplicate plots enabled assessment of how re-introduction for peatland restoration might interact with current burning regimes and burning undertaken for restoration purposes.

\section{Methods}

Three blanket peatland sites were chosen to represent key regions for this habitat in England; the Cheviot Hills, the North Pennine Hills, and the Peak District (Table 1). All three sites were managed for grouse shooting and had been burned on a rotational basis regularly for at least several decades. Their vegetation principally consisted of dwarf shrubs (mainly Calluna vulgaris), graminoids (including Eriophorum vaginatum and Eriophorum angustfolium) and mosses (a mix of pleurocarps, acrocarps and Sphagnum spp.), which occur in varying quantities at each site (Table 1).

At each site, five burn patches in each of three age categories were chosen with the help of land managers. Assessment of burn-age was based on site specific knowledge and morphology of $C$. vulgaris. After burning, C. vulgaris regenerates mainly from root stock and produces distinct new shoots during each year's growth season, which can be counted, enabling approximation of years since fire (Gimingham 1989). The youngest burn-age category (B1) comprised patches of vegetation burned approximately 12-18 months before the 
Table 1 Site locations, mean living cover of key vegetation groups (taken from summer 2016 surveys; \pm standard error) and modelled values for contemporary (2014-2016) atmospheric acid deposition (APIS 2018)

\begin{tabular}{lllllll}
\hline Site & Lat & Long & $\begin{array}{l}\text { Dwarf shrub } \\
\text { cover }(\%)\end{array}$ & $\begin{array}{l}\text { Graminoid } \\
\text { cover }(\%)\end{array}$ & $\begin{array}{l}\text { Moss cover (of } \\
\text { which Sphagnum) } \\
(\%)\end{array}$ & $\begin{array}{l}\text { Acid (keq } \\
\left.\text { ha }^{-1} \text { year }^{-1}\right)\end{array}$ \\
\hline Cheviot & 55.455 & -2.112 & $52 \pm 10$ & $19 \pm 6$ & $35 \pm 7(3 \pm 2)$ & 1.41 \\
North Pennine & 54.864 & -2.396 & $37 \pm 7$ & $54 \pm 6$ & $77 \pm 4(29 \pm 3)$ & 1.51 \\
Peak district & 53.233 & -1.980 & $45 \pm 8$ & $28 \pm 5$ & $69 \pm 4(<1 \pm<1)$ & 1.98 \\
\hline
\end{tabular}

All sites are on deep peat $(>40 \mathrm{~cm})$ and managed for grouse shooting

first survey in March 2016. The intermediate burn-age category (B5) comprised patches burned approximately 5 years before the first survey, and the oldest category $(\mathrm{B} 10+)$ comprised patches burned at least 10 years before the first survey.

Within each patch, two $1 \times 1 \mathrm{~m}$ plots were located $5 \mathrm{~m}$ apart and marked using bamboo canes. This gave a total of 30 plots per site; 5 pairs in each burn-age category. These plots were surveyed either four (Cheviot) or five (North Pennine and Peak District) times between March 2016 and October 2017. On each occasion, vegetation height and moss carpet thickness were measured at five points to $1 \mathrm{~cm}$ accuracy and the mean was recorded. Area cover of dwarf shrubs, graminoids, individual moss species, lichen, fungi, liverworts and other plants were recorded as percentages, as was cover of bare peat. For plants other than Sphagnum, only living cover was analysed. However, for Sphagnum both 'healthy' cover, and total cover including bleached patches, were analysed. Five plots (two pairs of B10+ plots and one B5 plot) were burned during the study at the Cheviot site and these were completely excluded from the analyses.

In July 2016, Sphagnum vegetative material was added to one of each pair of plots (a total of 45 plots over three sites). A mix of Sphagnum species representative of those present (comprising mainly $S$. capillifolium, with $S$. papillosum at the North Pennine and Cheviot sites and Sphagnum subnitens at the Peak District site) was collected at each site, and 10 'plugs' of approximately $4 \mathrm{~cm}$ diameter and $10 \mathrm{~cm}$ length, consisting of several Sphagnum stems with the capitula facing upwards were added to each plot. These were inserted into the existing moss layer or surrounded by the vascular plants present. The survival ('re-introduction success') of the added Sphagnum was assessed during three subsequent surveys on a semi-quantitative percentage scale, where scores ranged from 0, indicating that all added Sphagnum was dead, dried out or absent, to 100, indicating that all added Sphagnum appeared alive and healthy.

All statistical analyses were carried out using R 3.1.0 (R Development Core Team 2010) and the packages vegan (Oksanen et al. 2013), nlme (Pinheiro et al. 2016), 1smeans (Lenth 2016) and ggplot2 (Wickham 2009). Firstly, an exploratory Non-metric Multidimensional Scaling (NMDS) ordination was carried out on the multivariate vegetation data from all surveys on the plots without Sphagnum additions. This enabled visual inspection of how plots from different sites and burn-age categories differed in their vegetation composition by projecting them into a two-dimensional ordination space where plots with less similar vegetation are located further apart.

Linear mixed models were used to determine how vegetation characteristics (vegetation height, moss depth, bare ground cover), cover of plant taxonomic groups (dwarf 
shrubs, graminoids, pleurocarpous mosses, acrocarpous mosses, Sphagnum spp.) and Sphagnum re-introduction success varied according to site, burn-age category, time during the study, and the interactions between these variables. Aggregating individual moss species into groups enabled investigation of how groups of related species responded to predictor variables, including species which were too infrequent to analyse independently or absent from one or more sites. Dependent variables recorded as percentages were logit transformed for this analysis to satisfy model assumptions and improve fit, assessed by visual inspection of residual plots. Time during the study was treated as a continuous variable and was centred so that the mid-point of the study acted as the reference value. Plot ID was included in each model as a random effect to account for the repeat surveys. Least-squares means were compared (with Tukey's adjustment for multiple comparisons) to reveal significant differences between site and burn-age combinations. All differences described in the results are significant at $p<0.05$.

\section{Results}

The NMDS ordination results (Stress $=0.184, \mathrm{~K}=2$ ) suggest that vegetation communities differed according to both site and burn-age category. The North Pennine site was associated with the positive region of axis 1, whereas the Peak District and Cheviot sites were more associated with the negative region (Fig. 1a). Meanwhile, the most recently burned (B1) plots were more likely to fall in the positive region of axis 2, with the least recently burned plots $(\mathrm{B} 10+)$ falling in the negative region, and the intermediate (B5) plots were spread around the origin in both positive and negative regions (Fig. 1b).

Individual vegetation characteristics and taxonomic groups showed differences according to site and burn-age, and change over the course of the study for some variables (Online Resource 1). Bare peat was greater in B1 plots than B10+ plots at the Peak District site and greater in B1 plots than B5 and B10+ plots at the Cheviot site, with a decrease over time in the B1 plots (Fig. 2a). Moss depth was greater in B10+ plots than B1 plots at both the North Pennine and Peak District sites (Fig. 2b). Meanwhile, vegetation height was greater in B10+ plots than B1 plots at the Peak District and Cheviot sites and decreased over time in B1 plots at the North Pennine site (Fig. 2c).

Dwarf shrub cover increased over the study period in B1 plots at the Cheviot site and B1 and B5 plots at the North Pennine site. At all three sites B10+ plots had greater cover than B5 and B1 plots, and at the Cheviot site B5 plots also had greater cover than B1 plots (Fig. 3a). Graminoid cover increased over the study period in B1 plots at all three sites, but was greater in $\mathrm{B} 5$ plots than $\mathrm{B} 10+$ plots at the Cheviot site, greater in B1 plots than $\mathrm{B} 10+$ plots at the North Pennine site, and greater in both B1 and B5 plots than in B10+ plots at the Peak District site (Fig. 3b).

Pleurocarpous moss cover was greater at the Peak District site than the Cheviot site, and increased over the study period in Cheviot B1 plots, but showed no significant differences according to burn-age (Fig. 4a). Acrocarpous mosses increased over the study period in B1 plots at the Cheviot site (Fig. 4b). For existing Sphagnum, healthy cover increased over time in B1 plots at the North Pennine site (Fig. 5a), while total cover (including bleached areas) decreased over time in B1 plots at the Cheviot site (Fig. 5b). Cover of both healthy and total existing Sphagnum was greater at the North Pennine site than the other two sites (Fig. 5). 
Fig. 1 NMDS ordination of vegetation data from 201 blanket peatland plots showing a dissimilarities between plots according to site, $\mathbf{b}$ dissimilarities between plots according to burn-age (B1-burned 1 year before start of study, B5-burned c. 5 years before start of study, B10-burned at least 10 years before start of study) and c species associations (Aula.palu $=$ Aulacomnuim palustre, Camp. intr = Campylopus introflexus, Cera. purp $=$ Ceratodon purpureus, Dicr.maju = Dicranum majus, Hylo.sple = Hylocomium splendens, Hypn.jutl= Hypnum jutlandicum, Kind.prae $=$ Kind bergia praelonga, Plag. und $u=$ Plagiothecium und $u$ latum, Pleu.schr $=$ Pleurozium scherberi, Poly. stri = Polytrichum strictum, Rhyt.squa = Rhytidiadelphus squarrosus, Spha. capi = Sphagnum capillifolium, Spha.fall = Sphagnum fallax, Spha.mage = Sphagnum magel lanicum, Spha.papi= Sphagnum papillosum, Spha.subn = Sphagnum subnitens)

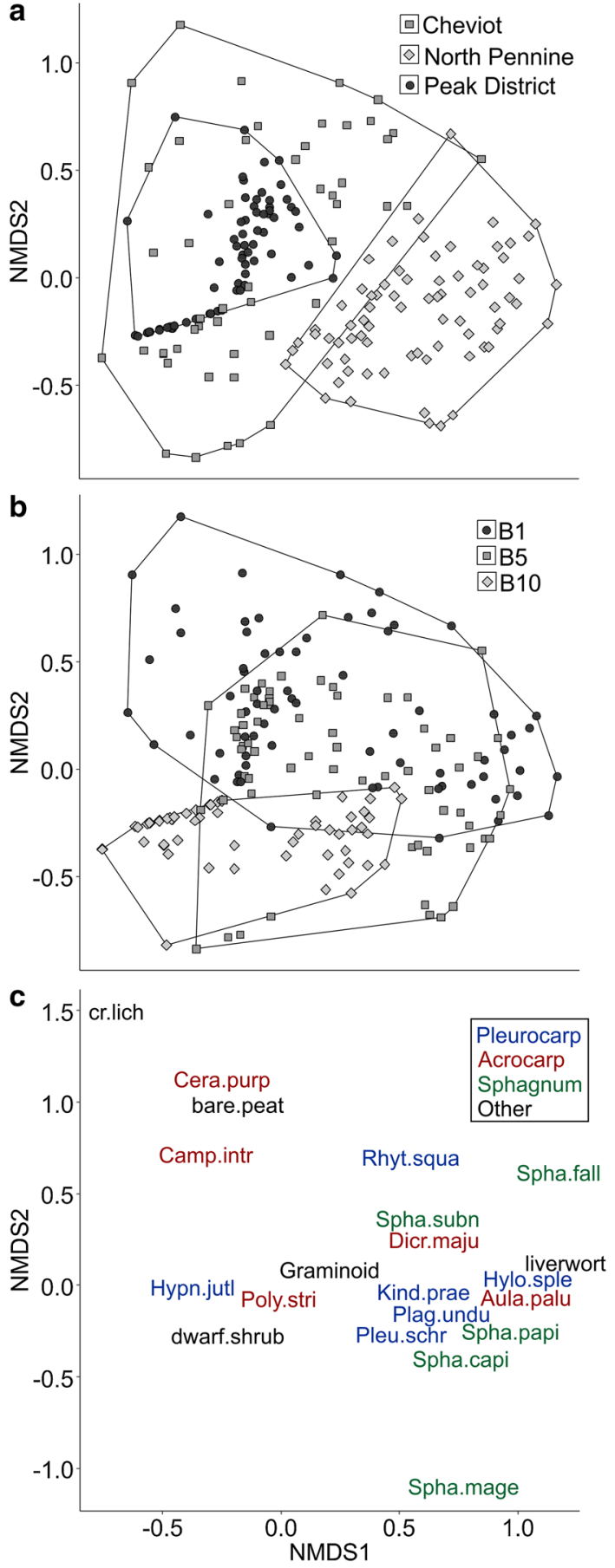




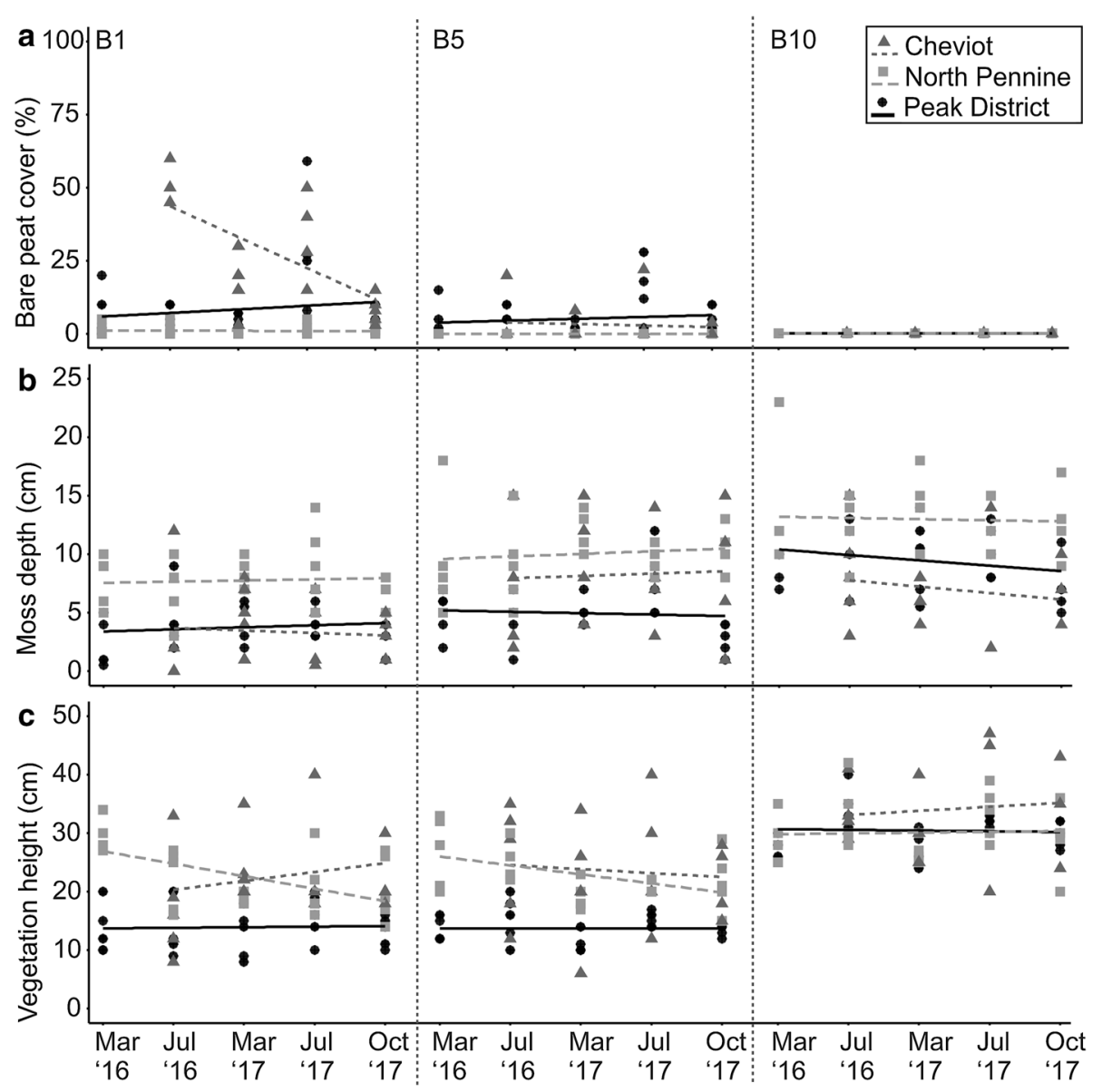

Fig. 2 Change over time with fitted relationships for a bare peat, $\mathbf{b}$ moss depth and $\mathbf{c}$ vegetation height according to site and burn-age category (B1-burned 1 year before start of study, B5-burned c.5 years before start of study, B10 — burned at least 10 years before start of study)

In plots where Sphagnum was added, there was no significant difference in re-introduction success according to burn-age. However, there was a decrease in success score over the recording period in B1 and B5 plots at the Peak District site. Success was greater at the North Pennine site than the Peak District site within the B1 category, and greater at the North Pennine site than the Cheviot site in the B10+category (Fig. 6).

\section{Discussion}

The NMDS ordination suggested that time since burning is an important factor in determining vegetation composition, alongside local site conditions. The B10+plots appeared to occupy a smaller area of the NMDS ordination than B1 or B5 plots, indicating greater similarity between plots, which could be the result of a few species or groups (such as dwarf shrubs) common to all three sites dominating at this stage of the burning cycle. 


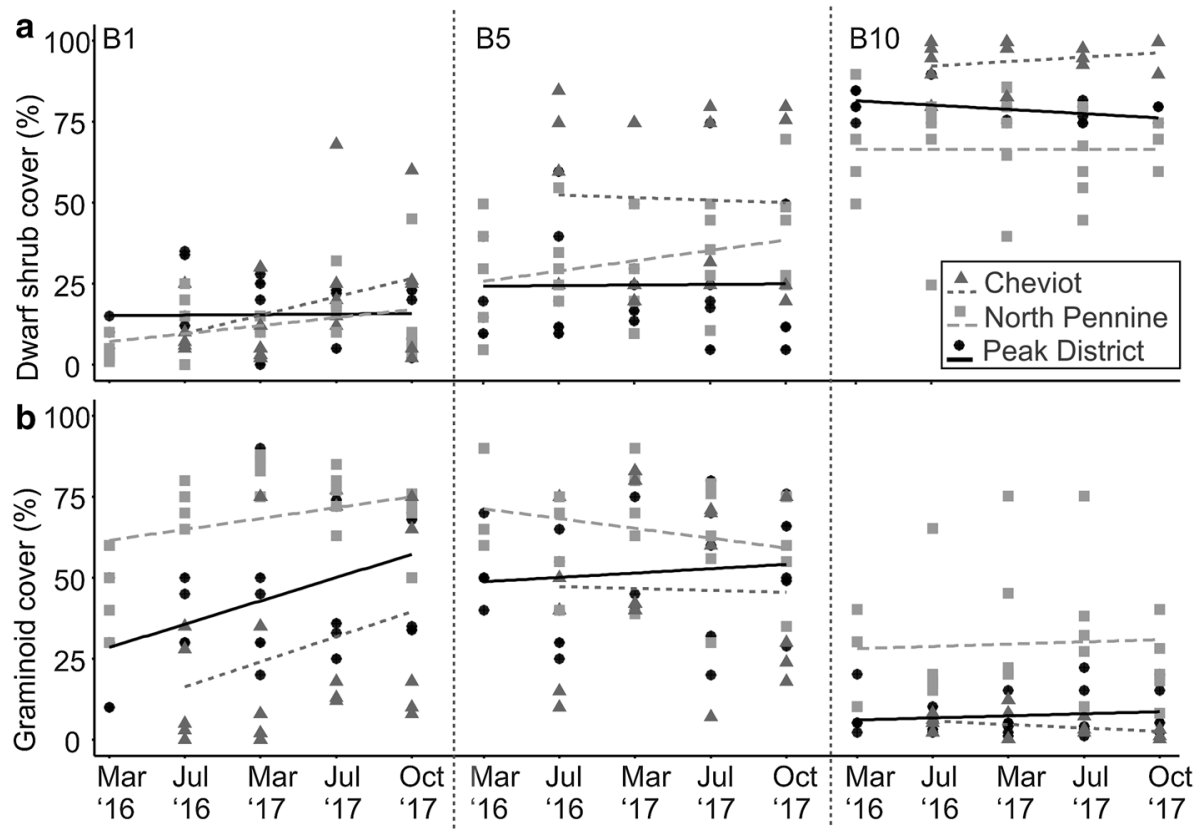

Fig. 3 Change over time with fitted relationships for a dwarf shrub cover and $\mathbf{b}$ graminoid cover according to site and burn-age category (B1-burned 1 year before start of study, B5-burned c.5 years before start of study, B10-burned at least 10 years before start of study)

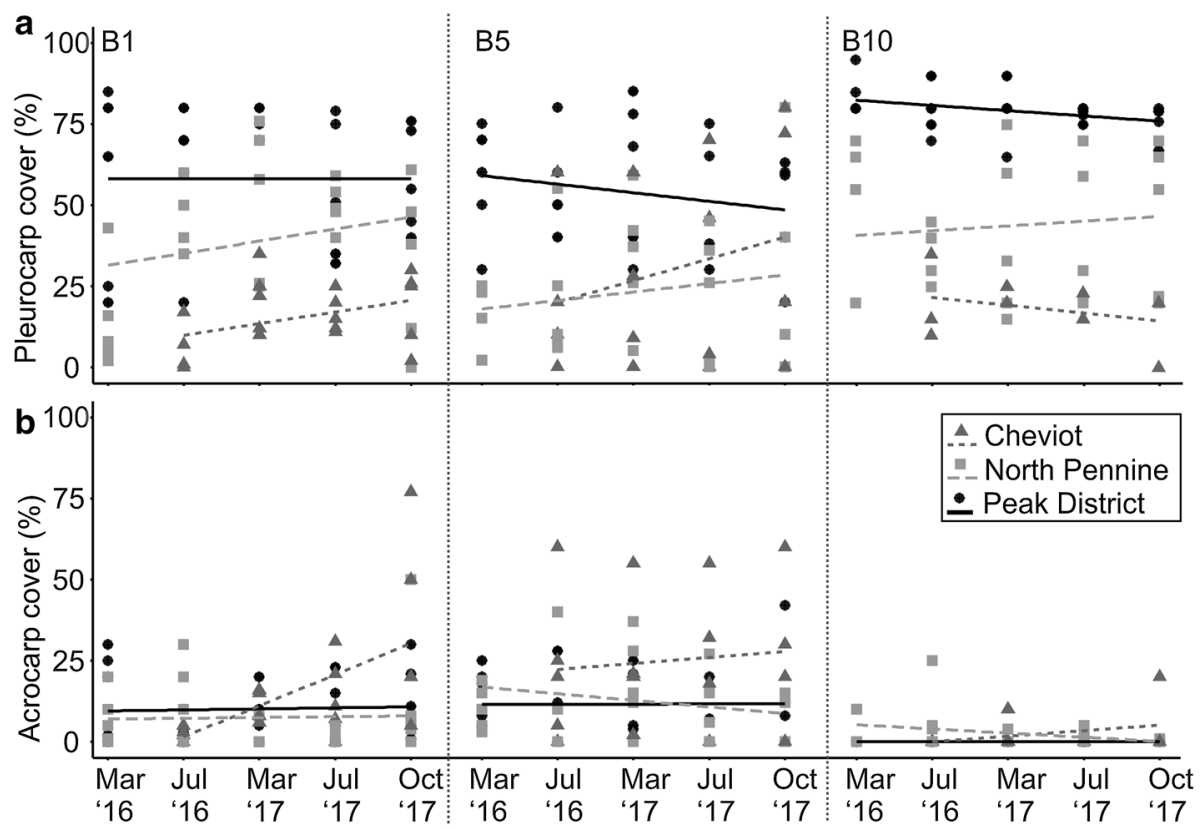

Fig. 4 Change over time with fitted relationships for a pleurocarpous moss cover and $\mathbf{b}$ acrocarpous moss cover according to site and burn-age category (B1-burned 1 year before start of study, B5-burned c.5 years before start of study, B10 - burned at least 10 years before start of study) 


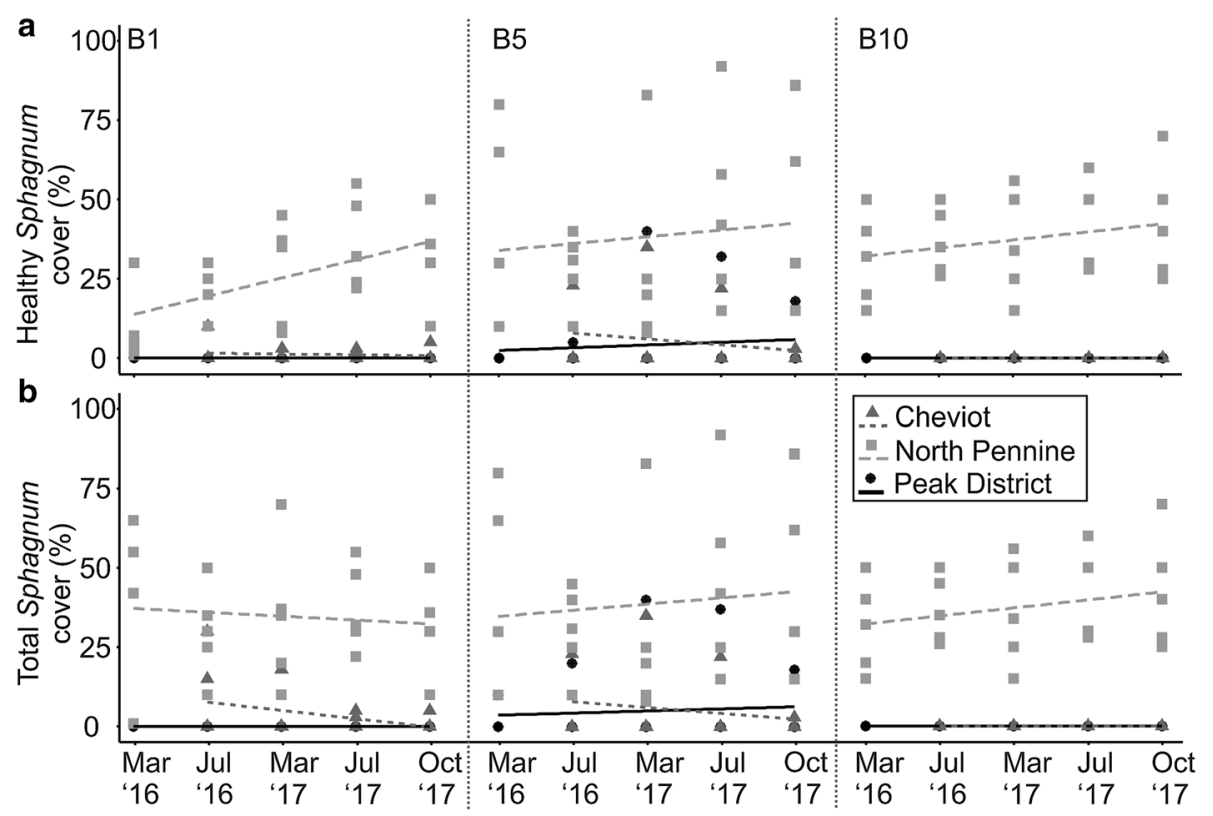

Fig. 5 Change over time with fitted relationships for a healthy Sphagnum cover and b total Sphagnum cover (including bleached patches) according to site and burn-age category (B1-burned 1 year before start of study, B5-burned c.5 years before start of study, B10-burned at least 10 years before start of study)

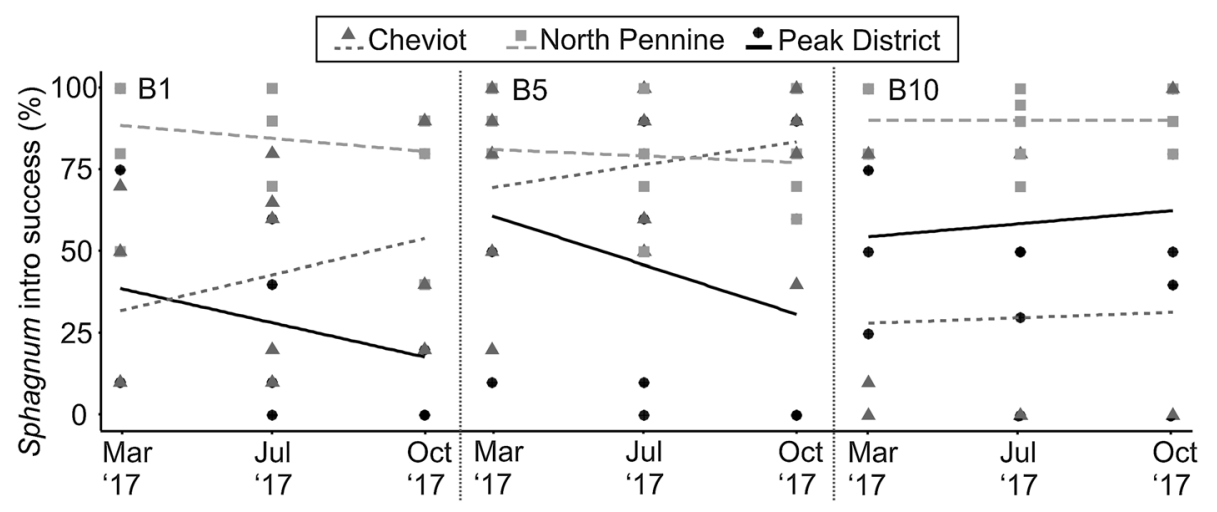

Fig. 6 Change over time with fitted relationships for Sphagnum re-introduction success according to site and burn-age category (B1-burned 1 year before start of study, B5-burned c.5 years before start of study, B10- burned at least 10 years before start of study)

The results of the univariate analyses suggest that burning can increase bare peat and cause thinning of the moss layer, probably due to moss being consumed or desiccated by fire. This is consistent with the reduced bryophyte biomass observed in more recently burned plots by Ward et al. (2007). Such changes could potentially result in faster overland flow (Holden et al. 2008), increased vulnerability to erosion (Holden et al. 2007), increased DOC in water courses (Yallop et al. 2010), and decreased carbon storage in the moss layer (Ward et al. 2007) in the years following burning. Bare peat was absent in the B10+plots, 
indicating that revegetation occurred within the rotational burning cycle at these sites. This suggests that effects of bare peat such as faster overland flow (Holden et al. 2008) are likely to be temporary. However, the extent of such effects will depend on the overall proportion of recently burned ground, which is dictated by the burning rotation length.

The lower vegetation height observed in the most recently burned plots at two out of three sites was expected owing to loss of canopy layer dwarf shrubs during fire. The decrease in vegetation height over time in B1 plots at the North Pennine site could be due to partially burned dwarf shrubs remaining after the burn before gradually reducing owing to mechanical damage from weather or trampling. The residual burned stems could indicate that burn severity was lower at the North Pennine site, a theory which is supported by the lower proportion of bare peat observed after burning compared to the other sites. Differences in burn severity can be a function of fuel structure and moisture (Davies and Legg 2011), wind speed (Santana and Marrs 2014) and burning technique (e.g. fuel assistance, fire direction relative to wind and patch size).

The peak in graminoid cover in the early years after burning, along with the continued increase in dwarf shrub cover suggest that burning on a shorter rotation may lead to graminoid dominance, while longer rotations are likely to favour greater dwarf shrub cover. This follows a similar pattern to past observations of burning effects on these groups (Harper et al. 2018; Lee et al. 2013; Ward et al. 2007). Past research suggests that fluctuations in the abundance of vascular plant groups are likely to lead to fluctuations in the export of DOC (Armstrong et al. 2012). The dwarf shrub dominance observed $10+$ years after burning could potentially lead to increased DOC in watercourses draining the catchment, with implications for the cost of water treatment where catchments supply potable water (Dixon et al. 2015).

Analysis of the three moss groups indicated that pleurocarpous mosses persist throughout the burning cycle. This could suggest fire tolerance in some pleurocarpous species, as well as tolerance to changes in light, moisture availability and soil water chemistry (Brown et al. 2014) during the burning cycle. Acrocarpous mosses increased over the study period in B1 plots at the Cheviot site, possibly owing to the higher proportion of bare peat at this site after burning. Ceratodon purpureus, an acrocarpous moss common in the Cheviot B1 plots, has previously been observed to colonise bare ground after fire (Duncan and Dalton 1982; Thomas et al. 1994), as have other acrocarpous mosses including Campylopus introflexus (Equihua and Usher 1993; Noble et al. 2018). It is possible that extensive colonisation by acrocarpous mosses after fire could negatively affect the regeneration of other vegetation owing to a tendency to rapidly carpet bare ground, providing a poor substrate for young plants of other species, and potentially competing for resources (Equihua and Usher 1993). However, the ecological consequences of such an effect require further research.

No significant impact of burning on Sphagnum was observed at the Peak District site, which had low overall abundance in all burn-age categories. At the North Pennine site where abundance was much higher, cover of healthy Sphagnum increased over time in the B1 plots. However, total Sphagnum cover (including bleached patches) remained constant in the same plots, suggesting that the increase in healthy Sphagnum represented the recovery of bleached patches which had been damaged as a result of fire. The temporary bleaching is likely to be associated with a reduction in photosynthetic efficiency (Taylor et al. 2017), potentially affecting growth rate and carbon balance during this period. In B1 plots at the Cheviot site, healthy Sphagnum cover remained constant, but total Sphagnum cover decreased over time, suggesting that some of the bleached patches did not recover and were lost. However, this trend over time was driven by relatively low cover in a few patches so caution is needed in interpreting this result. Differences in Sphagnum abundance (and vegetation composition more generally) between sites could be the result of variation in 
current and historic atmospheric pollution (Table 1), which is known to affect several peatland plants including Sphagnum (Noble et al. 2018). Other potential causes of differences between the sites include climate (e.g. temperature, rainfall, seasonality), management history (e.g. grazing, drainage, past fire) and other site specific factors (topography, peat physical properties). These factors may have contributed to the formation of different vegetation composition at the three sites and may have influenced Sphagnum abundance in particular via differences in water availability, nutrient availability and competition.

Sphagnum re-introduction success was consistently high at the North Pennine site, which also had the greatest existing Sphagnum abundance. This could indicate that Sphagnum abundance at the other two sites was limited by environmental factors, such as water availability, rather than propagule availability. At the Peak District site, Sphagnum re-introduction success declined over the study period in B1 and B5 plots. This effect could be due to Sphagnum plugs drying out over time, as these plots had less dwarf shrub cover and shorter vegetation so were more exposed, and potentially subject to hotter summer temperatures (Brown et al. 2015). These results do not support the theory that removing the dwarf shrub canopy benefits Sphagnum growth as suggested in current management guidance (Uplands Management Group 2017).

\section{Conclusions}

The results of this work suggest that different burning frequencies will result in different vegetation composition outcomes, with shorter rotations generally favouring graminoids and longer rotations favouring dwarf shrubs. Vegetation therefore has the potential to affect ecosystem services in different ways over the course of the burning cycle. The timescale and extent of vegetation change after burning varied between the three study sites, suggesting that some sites may be more resilient to burning. However, repeated burning, or stressors such as drainage, pollution, grazing or climate change could decrease resilience. Finally, this study found no evidence to suggest that burning is effective as a restoration tool to encourage Sphagnum, or that removing the canopy by burning increases Sphagnum re-introduction success.

Acknowledgements This analysis was funded by Natural Environment Research Council studentship [NE/ L008572/1] supported by Natural England, awarded to JH, SMP, DG and AC in open competition. We thank the gamekeepers and landowners at all three field sites for allowing access and contributing their time and expertise during the planning of the study. We are also grateful to members of Natural England and Northumberland National Park Authority for assistance finding field sites.

Data availability The dataset generated and analysed during this study will be made available in the Research Data Leeds repository, a DOI will be minted and provided in due course.

Open Access This article is distributed under the terms of the Creative Commons Attribution 4.0 International License (http://creativecommons.org/licenses/by/4.0/), which permits unrestricted use, distribution, and reproduction in any medium, provided you give appropriate credit to the original author(s) and the source, provide a link to the Creative Commons license, and indicate if changes were made.

\section{References}

Allen KA, Denelle P, Ruiz FMS, Santana VM, Marrs RH (2016) Prescribed moorland burning meets good practice guidelines: a monitoring case study using aerial photography in the Peak District, UK. Ecol Indic 62:76-85. https://doi.org/10.1016/j.ecolind.2015.11.030 
APIS (2018) Air Pollution Information System (APIS) Location-relevant pollution information. http://www. apis.ac.uk/search-by-location.

Armstrong A, Holden J, Luxton K, Quinton JN (2012) Multi-scale relationship between peatland vegetation type and dissolved organic carbon concentration. Ecol Eng 47:182-188. https://doi. org/10.1016/j.ecoleng.2012.06.027

Brown LE, Holden J, Palmer SM (2014) Effects of moorland burning on the ecohydrology of river basins. Key findings from the EMBER project. University of Leeds, Leeds

Brown LE, Palmer SM, Johnston K, Holden J (2015) Vegetation management with fire modifies peatland soil thermal regime. J Environ Manage 154:166-176. https://doi.org/10.1016/j.jenvm an.2015.02.037

Brown LE, Holden J, Palmer SM (2016) Moorland vegetation burning debates should avoid contextomy and anachronism: a comment on Davies et al. (2016). Philos Trans R Soc B. https://doi. org/10.1098/rstb.2016.0432

Campeau S, Rochefort L (1996) Sphagnum regeneration on bare peat surfaces: field and greenhouse experiments. J Appl Ecol 33:599-608. https://doi.org/10.2307/2404988

Carroll J, Anderson P, Caporn S, Eades P, O’Reilly C, Bonn A (2009) Sphagnum in the Peak Districtcurrent status and potential for restoration. Moors Future 6:1-121

Chirino C, Campeau S, Rochefort L (2006) Sphagnum establishment on bare peat: the importance of climatic variability and Sphagnum species richness. Appl Veg Sci 9:285-294. https://doi. org/10.2307/4620488

Clymo RS, Turunen J, Tolonen K (1998) Carbon accumulation in peatland. Oikos 81:368-388. https:// doi.org/10.2307/3547057

Davies GM, Legg CJ (2011) Fuel moisture thresholds in the flammability of Calluna vulgaris. Fire Technol 47:421-436. https://doi.org/10.1007/s10694-010-0162-0

Dixon SD, Worrall F, Rowson JG, Evans MG (2015) Calluna vulgaris canopy height and blanket peat CO2 flux: implications for management. Ecol Eng 75:497-505. https://doi.org/10.1016/j.ecoleng.2014.11.047

Douglas DJT, Buchanan GM, Thompson P, Amar A, Fielding DA, Redpath SM, Wilson JD (2015) Vegetation burning for game management in the UK uplands is increasing and overlaps spatially with soil carbon and protected areas. Biol Conserv 191:243-250. https://doi.org/10.1016/j.biocon.2015.06.014

Duncan D, Dalton PL (1982) Recolonisation by bryophytes following fire. J Bryol 12:53-63. https://doi. org/10.1179/jbr.1982.12.1.53

Elumeeva TG, Soudzilovskaia NA, During HJ, Cornelissen JHC (2011) The importance of colony structure versus shoot morphology for the water balance of 22 subarctic bryophyte species. J Veg Sci 22:152-164. https://doi.org/10.1111/j.1654-1103.2010.01237.x

Equihua M, Usher MB (1993) Impact of carpets of the invasive moss campylopus introflexus on Calluna vulgaris regeneration. J Ecol 81:359-365. https://doi.org/10.2307/2261506

Evans CD, Bonn A, Holden J, Reed MS, Evans MG, Worrall F, Parnell M (2014) Relationships between anthropogenic pressures and ecosystem functions in UK blanket bogs: linking process understanding to ecosystem service valuation. Ecosyst Serv 9:5-19. https://doi.org/10.1016/j.ecoser.2014.06.013

Ferguson P, Lee JA, Bell JNB (1978) Effects of sulphur pollutants on the growth of Sphagnum species. Environ Pollut 16:151-162. https://doi.org/10.1016/0013-9327(78)90129-5

Ferland C, Rochefort L (1997) Restoration techniques for Sphagnum-dominated peatlands. Can J Bot 75:1110-1118

Garnett MH, Ineson P, Stevenson AC (2000) Effects of burning and grazing on carbon sequestration in a Pennine blanket bog, UK. Holocene 10:729-736. https://doi.org/10.1191/09596830094971

Gimingham CH (1989) Heather and heathlands. Bot J Linn Soc 101:263-268

Grayson R, Holden J, Rose R (2010) Long-term change in storm hydrographs in response to peatland vegetation change. J Hydrol 389:336-343. https://doi.org/10.1016/j.jhydrol.2010.06.012

Gunnarsson U, Rydin H (2000) Nitrogen fertilization reduces Sphagnum production in bog communities. New Phytol 147:527-537. https://doi.org/10.1046/j.1469-8137.2000.00717.x

Gunnarsson U, Söderström L (2007) Can artificial introductions of diaspore fragments work as a conservation tool for maintaining populations of the rare peatmoss Sphagnum angermanicum? Biol Conserv 135:450-458. https://doi.org/10.1016/j.biocon.2006.10.014

Harper AR, Doerr SH, Santin C, Froyd CA, Sinnadurai P (2018) Prescribed fire and its impacts on ecosystem services in the UK. Sci Total Environ 624:691-703. https://doi.org/10.1016/j.scitotenv.2017.12.161

Harris A (2008) Spectral reflectance and photosynthetic properties of Sphagnum mosses exposed to progressive drought. Ecohydrology 1:35-42. https://doi.org/10.1002/eco.5

Hinde S, Rosenburgh A, Wright N, Buckler M, Caporn S (2010) Sphagnum re-introduction project: a report on research into the re-introduction of Sphagnum mosses to degraded moorland. Moors Future Res Rep 18:1-31 
Holden J, Shotbolt L, Bonn A, Burt TP, Chapman PJ, Dougill AJ, Worrall F (2007) Environmental change in moorland landscapes. Earth Sci Rev 82:75-100. https://doi.org/10.1016/j.earscirev.2007.01.003

Holden J, Kirkby MJ, Lane SN, Milledge DG, Brookes CJ, Holden V, McDonald AT (2008) Overland flow velocity and roughness properties in peatlands. Water Resour Res 44:W06415. https://doi. org/10.1029/2007WR006052

IUCN (2017) Position Statement: Burning and peatlands. IUCN UK Peatland Programme, Edinburgh. http://www.iucn-uk-peatlandprogramme.org/resources/position-paper-burning-and-peatlands

Kalnina L, Stivrins N, Kuske E, Ozola I, Pujate A, Zeimule S, Ratniece V (2015) Peat stratigraphy and changes in peat formation during the Holocene in Latvia. Quat Int 383:186-195. https://doi. org/10.1016/j.quaint.2014.10.020

Labadz J, Allott TEH, Evans M, Butcher D, Billett M, Stainer S, et al (2010) Peatland hydrology. IUCN UK Peatland Programme Draft Scientific Review

Lee H, Alday JG, Rose RJ, O'Reilly J, Marrs RH (2013) Long-term effects of rotational prescribed burning and low-intensity sheep grazing on blanket-bog plant communities. J Appl Ecol 50:625-635. https:// doi.org/10.1111/1365-2664.12078

Lenth RV (2016) Least-squares means: the R Package lsmeans. J Stat Softw 69:1-33

Littlewood N, Anderson P, Artz RRE, Bragg OM, Lunt P, Marrs RH (2010) Peatland biodiversity. IUCN UK Peatland Programme Draft Scientific Review

Lunt P, Allott TEH, Anderson T, Buckler M, Coupar A, Jones P, Worrall F (2011) Peatland restoration. Edinburgh: Report to IUCN UK Peatland Programme. http://www.iucn-uk-peatlandprogramme.org/ publications/commission-inquiry/work-commission/peatland-restoration

Malmer N, Svensson BM, Wallén B (1994) Interactions between Sphagnum mosses and field layer vascular plants in the development of peat-forming systems. Folia Geobot Phytotaxon 29:483-496. https://doi. org/10.2307/4181306

McClymont EL, Bingham EM, Nott CJ, Chambers FM, Pancost RD, Evershed RP (2011) Pyrolysis GC-MS as a rapid screening tool for determination of peat-forming plant composition in cores from ombrotrophic peat. Org Geochem 42:1420-1435. https://doi.org/10.1016/j.orggeochem.2011.07.004

Nichols JE, Peteet DM, Moy CM, Castañeda IS, McGeachy A, Perez M (2014) Impacts of climate and vegetation change on carbon accumulation in a south-central Alaskan peatland assessed with novel organic geochemical techniques. The Holocene 24:1146-1155. https://doi.org/10.1177/0959683614540729

Noble A, Palmer SM, Glaves DJ, Crowle A, Holden J (2017) Impacts of peat bulk density, ash deposition and rainwater chemistry on establishment of peatland mosses. Plant Soil 1:2. https://doi.org/10.1007/ s11104-017-3325-7

Noble A, Palmer SM, Glaves DJ, Crowle A, Brown LE, Holden J (2018) Prescribed burning, atmospheric pollution and grazing effects on peatland vegetation composition. J Appl Ecol 55:559-569. https://doi. org/10.1111/1365-2664.12994

Oksanen J, Blanchet FG, Kindt R, Legendre P, Minchin PR, O’Hara RB, Simpson GL, Solymos P, Stevens MH, Wagner H (2013) vegan: community ecology package. R package version 2.0-10. http://CRAN.Rproject.org/package $=$ vegan

Orwin KH, Ostle NJ (2012) Moss species effects on peatland carbon cycling after fire. Funct Ecol 26:829_ 836. https://doi.org/10.1111/j.1365-2435.2012.01991.x

Pinheiro J, Bates D, DebRoy S, Sarkar D, R Development Core Team (2016) nlme: linear and nonlinear mixed effects models. http://CRAN.R-project.org/package $=$ nlme

Price JS, Whitehead GS (2001) Developing hydrologic thresholds for Sphagnum recolonization on an abandoned cutover bog. Wetlands 21:32-40. https://doi.org/10.1672/0277-5212(2001)021\%5b0032:dhtfs r\% 5d2.0.co;2

R Development Core Team (2010) R: a language and environment for statistical computing. R Foundation for Statistical Computing. Vienna, Austria. http://www.R-project.org/

Ritson JP, Bell M, Brazier RE, Grand-Clement E, Graham NJD, Freeman C, Smith D, Templeton MR, Clark JM (2016) Managing peatland vegetation for drinking water treatment. Sci Rep 6:36751. https:// doi.org/10.1038/srep36751

Robertson GS, Newborn D, Richardson M, Baines D (2017) Does rotational heather burning increase red grouse abundance and breeding success on moors in northern England? Wildl Biol. https://doi. org/10.2981/wlb.00227

Robroek BJM, van Ruijven J, Schouten MGC, Breeuwer A, Crushell PH, Berendse F, Limpens J (2009) Sphagnum re-introduction in degraded peatlands: the effects of aggregation, species identity and water table. Basic Appl Ecol 10:697-706. https://doi.org/10.1016/j.baae.2009.04.005

Santana VM, Marrs RH (2014) Flammability properties of British heathland and moorland vegetation: models for predicting fire ignition. J Environ Manage 139:88-96. https://doi.org/10.1016/j.jenvm an.2014.02.027 
Taylor ES, Levy PE, Gray A (2017) The recovery of Sphagnum capillifolium following exposure to temperatures of simulatedmoorland fires: a glasshouse experiment. Plant Ecol Divers 10:77-88. https:// doi.org/10.1080/17550874.2017.1302017

Thacker JI, Yallop AR, Clutterbuck B (2015) Burning in the English uplands_-a review, reconciliation and comparison of results of natural england's burn monitoring: 2005-2014. Improvement Programme for England's Natura 2000 Sites (IPENS), 055

Thomas PA, Proctor MCF, Maltby E (1994) The ecology of severe Moorland fire on the North York Moors: chemical and physical constraints on moss establishment from spores. J Ecol 82:457-474. https://doi. org/10.2307/2261255

Thompson DBA, MacDonald AJ, Marsden JH, Galbraith CA (1995) Upland heather moorland in Great Britain: a review of international importance, vegetation change and some objectives for nature conservation. Biol Conserv 71:163-178. https://doi.org/10.1016/0006-3207(94)00043-P

Uplands Management Group (2017) Blanket bog outcomes and improvements land management guidance, MoorLIFE 2020

van Breemen N (1995) How Sphagnum bogs down other plants. Trends Ecol Evol 10:270-275. https://doi. org/10.1016/0169-5347(95)90007-1

Ward SE, Bardgett RD, McNamara NP, Adamson JK, Ostle NJ (2007) Long-term consequences of grazing and burning on northern peatland carbon dynamics. Ecosystems 10:1069-1083. https://doi. org/10.1007/s10021-007-9080-5

Wickham H (2009) ggplot2: elegant graphics for data analysis. Springer, New York

Xu J, Morris PJ, Liu J, Holden J (2018) PEATMAP: refining estimates of global peatland distribution based on a meta-analysis. CATENA 160:134-140. https://doi.org/10.1016/j.catena.2017.09.010

Yallop AR, Thacker JI, Thomas G, Stephens M, Clutterbuck B, Brewer T, Sannier CAD (2006) The extent and intensity of management burning in the English uplands. J Appl Ecol 43:1138-1148. https://doi. org/10.1111/j.1365-2664.2006.01222.x

Yallop AR, Clutterbuck B, Thacker J (2010) Increases in humic dissolved organic carbon export from upland peat catchments: the role of temperature, declining sulphur deposition and changes in land management. Clim Res 45:43-56

Yu Z, Loisel J, Brosseau DP, Beilman DW, Hunt SJ (2010) Global peatland dynamics since the Last Glacial maximum. Geophys Res Lett. https://doi.org/10.1029/2010g1043584 